\title{
THE ATTRACTIVENESS OF KINESICS IN A SEMIOPRAGMATIC PERSPECTIVE: A STUDY ON LANGUAGE LEARNING I Wayan Ardi Sumarta ${ }^{1 *}$, I Wayan Simpen ${ }^{2}$, I Ketut Darma Laksana ${ }^{3}$, Ketut Artawa ${ }^{4}$
}

${ }^{1}$ Indonesian Education and Literature Program, Faculty of Education and Teacher Training, Universitas Lampung, Lampung, Indonesia; ${ }^{2,3,4}$ Lingusitic Program, Faculty of Cultural Studies, Universitas Udayana, Bali, Indonesia. Email: ${ }^{1 *}$ wayanardisumarta@gmail.com, ${ }^{2}$ wynsimpen60@gmail.com, ${ }^{3}$ darmalaksana2020@gmail.com, ${ }^{4}$ ketut_artawa@unud.ac.id

\section{Article History: Received on $24^{\text {th }}$ March 2020, Revised on $24^{\text {th }}$ April 2020, Published on $16^{\text {th }}$ May 2020}

\begin{abstract}
Purpose of the study: Language is a productive communication tool for teachers to interact with learners. The use of non-verbal Language in speaking becomes strong support when the speech event takes place. This study aims to determine the elements of kinesics and politeness of the Language of the instructor in learning.
\end{abstract}

Methodology: The method used in this study uses descriptive methods. The subjects involved in the research were one lecturer in Indonesian language courses andMahasaraswati university students who were taking Indonesian language courses. The study was conducted in 6 different classes for three meetings.

Main Findings: The results showed that non-verbal Language is inherent and contributes to the application of the instructor's politeness principle in learning. Utilization of kinesics in the politeness of Language perfects a speech that is based on the politeness of Language so that the care of speech harmony can be sustained and to the success in maintaining the face of the speech partner especially emotional closeness between learners and instructors.

Application of this study: Learning includes embedded values and imprinted into a role model for learners. The attitude that is no less important and inherent in the instructor's self is the kinesic attraction that causes the learner's pleasure and comfort when learning takes place.

Novelty/Originality of this study: Research in Indonesian has not yet led to politeness in Language. The utilization of non-verbal Language in speaking becomes strong support when the speech event takes place, this is because Language is the main communication tool for interaction in learning.

Keywords: Kinesics, Politeness, Language learning, Semiopragmatic, Communication, Attractiveness.

\section{INTRODUCTION}

Humans as social creatures, wherein these social activities humans interact with each other. Social interaction is an activity where Language becomes the main means of interaction. In interacting with others there are different insights in each human, thus when interacting with humans as social beings contribute to each other's thoughts in the pragmatic context. Pragmatics is the study of the ability to use Language, in associating sentences with the context that is appropriate for the sentence (Mey, 2009). In other words, pragmatic learns about the meaning of sentences spoken by speakers adjusted to the context and situation.

Exchange of ideas can also occur in learning; one of them is learning Indonesian. In the learning process, teachers use Language as a communication tool. Communication has a significant place in education and training, as in all aspects of life (Gulec \& Temel, 2015). In this case, educators must have effective communication skills because they have an impact on the teaching of educators. Having good communication skills is one of the main professional criteria that influence the quality of teaching and learning (Gulec \& Temel, 2015). Communication that takes place in teaching and learning activities involves a speech event.

Speech events that require a component of the speaker and interlocutor, in this case, the instructor and learner. The speech that takes place between speakers who change roles is motivated by the purpose of each speech. For example, speech between an employee and his supervisor, a trader and his trading partner, and also a speech between the academic community of lecturers and students or students and their teachers.

Speech event is the occurrence or ongoing linguistic interaction in the form of utterances or more involving two parties, namely the speaker and interlocutor, with one main speech, in a particular time, place, and situation (Chaer \& Agustina, 2004). In the event of speech, there is the term politeness in Language that can be seen from real conditions. The use of slang now has dominated the style of students' Language; this makes students often get too far using slang without seeing who the other person is speaking with. However, educators also sometimes trigger abusive Language when in an emotional state.

Politeness is a procedure and rules in society to behave with others. In other words, politeness can be said as a karmic order 
in Language. The speech must contain the values and norms of the community that can create the comfort of speakers as well as speech partners. Therefore, every speaker must carry the mission of always maintaining the comfort of the speech partner in speaking. A person learns from childhood in his life about ethics and politeness norms. Likewise, in Language, there is important language ethics applied by speakers and speech partners. Language ethics is closely related to the selection of language codes, social norms, and cultural system that applies in a society. Therefore, this language ethic will "regulate" among other things (a) what must be said at certain times and circumstances to a participant of course about social and cultural status in the community; (b) what languages are most appropriate to be used in certain sociolinguistic and cultural situations; (c) when and how to use turn to talk, and interrupt the conversation of others; (d) when to be quiet; (e) what is the sound quality and attitude in speaking.

Someone can be said to be good at the Language if you master the language procedures or ethics (Chaer \& Agustina, 2004). This component is the background of speech because all speeches have a purpose (Tarigan, 1993). Therefore, speakers need to master how to speak well so that all the speeches they want to convey to their interlocutors can be well received. Language ethics contains all forms of speech both verbal and non-verbal speech. The application of politeness in speaking can be made by applying maxims in conversation. In addition to applying language politeness, to maximize the success of speech and to maintain harmony in speech events it is important to pay attention to the non-verbal forms of Language. Non-verbal communication is to convey emotions, feelings, or convey messages through the expression of movements or actions (Hans \& Hans, 2015). In everyday life, non-verbal and verbal communication can go hand in hand. Sometimes even non-verbal communication is a way to express emotions or feelings better than using words.

Facial expression is one of the most common strategies of non-verbal communication, which is sometimes mistakenly referred to as body language (kinesic) (Caffi \& Janney, 1994). The word kinesics comes from the basic word kinesis, which means "movement," and refers to the study of the movements of the hands, arms, body, and face (Hans \& Hans, 2015; Kliem, 2007). Based on these definitions, it can be understood that kinesics (the science of motion) is the study of the meaning of the movements conveyed by speakers (Birdwhistell, 1955). So that in kinesics research can be done through observation activities.

Birdwhistell (Birdwhistell, 1955) expressed seven basic assumptions of kinesics theory including: (1) All body movements have important meanings in the context of communication; (2) Behavior can be analyzed because it is regulated and this arrangement can be peeled with systematic analysis; (3) Although bodily activities have biological limitations, the use of bodily movements in interactions is considered to be a part of the social system; (4) People are affected by other people's visible body activities; (5) Ways the body's activities that function in communication can be investigated; (6) The meaning revealed in the results of kinesics research comes from the behavior that has been studied as the method being studied for research; (7) A person who uses bodily activities will have idiosyncratic characteristics, but will also be part of a large social system (Birdwhistell, 1955). One of the classic movements about kinesics in daily life is in the form of gestures. For example, to say "yes" in kinesics nodding and to say "no" in kinesics by shaking your head. Kinesics study by observing the observation of the signs "yes" and "no" is a study of how kinesics studies can occur in different lives, although there are many similarities. For example, raising an eyebrow, universally, states "yes" and shakes his head to say "no" in social interactions (Chaer \& Agustina, 2004).

The attractiveness of kinesics contributes to the success of speech based on language politeness, which involves eye contact between speakers and speech partners (Chiu \& Babcock, 2002). For example, a student might not speak politely but when speaking his eyes and hand gestures while operating his cellphone while communicating with his lecturer. Likewise, a lecturer who is teaching must utilize his kinesic skills to create a higher level of concentration and make students feel an emotional attachment to the lecturer. The activity can also be realized by the example of the relationship between male lecturers and male students so that the kinesic form of the lecturer can take the act of gently holding and patting the shoulders of the student when the student asks as a form of appreciative action.

The kinesics attraction that the lecturer or teacher has and a good understanding of this movement by students are also important in speech events (Chiu \& Babcock, 2002; Gulec \& Temel, 2015; Jolly, 2000). Therefore, a speaker (lecturer or teacher) in the 21 st century not only has professional knowledge but also who is acquainted with speech partners and organizes educational activities that are appropriate for speech partners (Gulec \& Temel, 2015). Speakers need to master the form of non-verbal Language in politeness as an effort to maximize language ethics and efforts to increase harmony or emotional closeness between speakers. Given non-verbal communication (Non-Verbal Communication, NVC) occurs whenever someone interacts with others, intentionally or unintentionally is part of the communication that occurs between two individuals (Gabbott \& Hogg, 2000; Gkorezis, Bellou, \& Skemperis, 2015). The learning process is the time to transfer knowledge and exchange ideas. The event lasted a long time and in a continuous-time.

\section{AIM OF THE STUDY}

Therefore, a teacher and also a learner need to maintain harmonious relationships and emotional ties so that both the goals behind the speech events occur can always be maintained. This research focuses on the attractiveness of kinesics in 
politeness in Language with aims to determine the elements of kinesics and politeness of the Language of the instructor in learning.

This issue is essential to be studied so that speakers can empower the value of kinesics in speech based on politeness in language ethics.

\section{LITERATURE REVIEW}

Particular of social actions or behavior in the public as accepted to be common values is called politeness. Therefore, this politeness of Language is also called "manners" in Language. The politeness of a person's Language can be measured by several types of politeness scale. Chaer \& Agustina (Chaer \& Agustina, 2004) states that what is meant by the courtesy scale is the rank of politeness, starting from the impolite to the most polite. Rahardi (Rahardi, 2005) states that the three categories of levels in politeness are generally applied for research.

Language reflects the nation. That is the slogan that we often hear. Indeed, a person's speech acts not only reflect the person's geographical identity but also reflect the quality of that person. An educated person, he must be able to use Language well, according to the context in which the right, and the right choice of words and sentences (Jolly, 2000; Jung \& Yoon, 2011). Besides, with Language, people can communicate with each other, establish cooperation, and respect for others.

Conversely, with Language, people can ignite fights, fights, wars, even with Language, people can destroy the world. Thus it is clear that Language plays an important role in maintaining harmony in life in society and the country (Jolly, 2000; Jung \& Yoon, 2011; Kaiser, Glatte, \& Lauckner, 2019). The use of polite Language will minimize friction and conflict. While the use of Language that is not polite can lead to conflicts that often cause fights, fights, and even war. Not infrequently wars that occur between communities, even between countries provoked by statements of leaders in Language that is not friendly.

The human body can speak complex and structured languages, which are commonly referred to in the literature as body language or nonverbal Language, which is recently known as kinesics (Dil, 1978). Understandably, words and sentences can not stand alone, while nonverbal messages are more meaningful and significant. Nonverbal cues generally provide information related to the affective aspects of communication. Most of the effects of language use are stated nonverbally (Dil, 1978; Gkorezis et al., 2015). The communication skills delivered by a teacher in class are important factors in determining how effectively he is considered capable of teaching (Buck \& Tiene, 1989).

Goebel and Cashen found that attractiveness was associated with higher levels of most indicators of teaching performance in the classroom (Buck \& Tiene, 1989). So that the attraction of kinesics relates to the inculcation of values to be conveyed to the speech partners. Having good communication skills is one of the main professional criteria that is influential in teaching, which is the communication profession. Because an individual needs to get the right listening and speaking habits to express it in a better way and to understand others better (Gulec \& Temel, 2015).

From another perspective, we observe that non-verbal communication is effective when verbal communication is inadequate or verbal communication cannot be provided (Gkorezis et al., 2015). For example, a teacher does not need to disturb the course to make students calm because he can make eye contact with students through body language while teaching. This situation can be considered important because the teacher has effective body language skills and shows the importance of body language (Gulec \& Temel, 2015).

Most of the effects of language use are stated nonverbally (Dil, 1978). Because nonverbal communication media far exceeds verbal communication media that are exclusively received through the auditory channel and expressed through the speech mechanism. In kinesics, hands, head, eyes, mouth, nose, forehead, face, body, and space are potential contributors (Dil, 1978). The experience given in previous studies shows that kinesics might be more suitable to be presented to students as a process rather than a product (English, 1986). The communication skills delivered by a teacher in the classroom are important factors in determining teacher teaching performance (Buck \& Tiene, 1989). Also, social psychologists have found that physical appearance can significantly influence how people are perceived and evaluated (Buck \& Tiene, 1989). This shows that the appearance or nature of the lecturer in delivering the material greatly affects the comfort of student learning.

One of the most important determinants of NVC communication is gender. Put, men and women code and interpret different communication cues (Gabbott \& Hogg, 2000). Men talking to men will use NVC differently from men talking to women, and women are more trusting and open with other women. Women generally smile more (and frown less), an approach that is closer than men, less restless, and makes more eye contact, especially when listening. Men have a higher level of touch avoidance than women and women respond more positively to touch (as appropriate) because they consider it friendly (Gabbott \& Hogg, 2000). These differences are important for service providers, especially when considering the formation of empathy or control (Gabbott \& Hogg, 2000). 


\section{METHODS}

\section{Research Design}

In general, this study aims to determine the elements of kinesics and politeness of the instructor's Language in learning. And to find out the benefits of kinesics power and politeness in the Language in learning. The method used in this study uses descriptive methods. Sugiyono (Sugiyono, 2013) states that it is applied to draw a specific explanation in narrative ways for a detailed conclusion. So it can be said that by using descriptive methods researchers try to describe a symptom, an event that is happening at present or an actual problem.

\section{Research Sample}

The subjects involved in the research were one lecturer in Indonesian language courses and 34 semesters one Mahasaraswati university students who were taking Indonesian language courses. The study was conducted in 6 different classes, for 3 meetings. The baseline in choosing the sample of the study was taken only for those who were studying the Indonesian Language as one of the compulsory subject learned at the university level.

\section{Instrument and Procedures}

In this case, it describes the attraction of kinesics and the politeness of the instructor's Language in a study. The instrument used in the study was an observation sheet, it aims to observe "movements," or kinesics, and refers to studies of hand, arm, body, and face movements (Hans \& Hans, 2015). So that in kinesics research can be done through observation activities.

\section{RESULT AND DISCUSSION}

\section{Courage in Language in Learning}

The politeness of the Language of the speaker and the speech partner is the teacher and the learner. Learning takes place in at least one and a half hours or $2 \times 50$ minutes. Teachers' activities in the learning classroom become the main because the puppeteer and class controller are the instructors. The forms of kinesic motion that were discovered and made observations in this study became interesting focusing on how learners respond when learning. Do laugh, smile, nod, and express other comfortable attitudes. Researchers focus on the object in the semiotic approach. The objects include the Icons, Index, and Symbol sections. The three parts of the object are used as dissectors, analyzers, and classifiers of the kinesic motion of the instructor and learner in learning. Meaning icons are signs or objects similar to the original (Ratna, 2009). As in the photo with the original figure referred to in the photo. Study Icons found on teacher data. The teacher imitates the style of a comic or comedian at stand-up comedy.

\section{Data 1. Field Note 1:}

The teacher stood firm sighed looked at the student as straight as and said at the fragment of the introduction "my mother is Javanese, Javanese people who hold European culture tightly".

These utterances are often spoken by famous comics in Indonesia named Dodit. The icons in this research data are the duplication of character, standing style, even the style of inserting a hand into a pants pocket that is identical to the style of a comic named Dodit (the situation referred to the character the learner imitates understands and knows).

Data 2. Field Note 2:

The bespectacled instructor and lowered his glasses to the tip of the nose and although not bald, the instructor showed the width of his forehead by covering his hair using his palm (intending to refer to the figure of a motivator named Mario Teguh) then said in Mario Teguh's style when giving motivation.

A second action is a form of icon against a public figure of a motivator named Mario Teguh. When the learners laughed and carried away the atmosphere of the joke the teacher displayed. The index is a significant relationship that is causal or related to causal relations (Ratna, 2009). As the example explained is related to if there is smoke there must be fire.

Data 3. Field Note 3:

A learner successfully answers questions raised by the teacher. Immediately the teacher stands up and applauds and asks all students in the class to applaud to appreciate the answer given by the learner.

Symbols relating to objects or agreements that have been made and agreed together (Ratna, 2009). For example, people agree on traffic signs that red lights make motorists stop, yellow lights get ready, and are careful, then if the lights turn green all drivers are expected to run their vehicles. 
Data 4. Field Note 4:

Previously they (instructors and learners) already had a learning contract related to the time of entry and end of class. Once a learner was late, a teacher looked at his watch and shook his head.

Activity Symbols agreed upon by the instructor and learner make the communication process unnecessary to make the learner feel severely punished. With this agreement, the learner is very aware of his mistakes and the teacher without having to threaten his emotional closeness; he is sure that the learner understands and will not repeat the violations in question.

\section{Data 5. Field Note 5:}

The learner stands up and raises the marker for who the learner is willing to try to answer the question from the teacher and writes the answers on the board. Learners raise their hands, and instructors invite learners to come forward and try to answer the problems given.

Data 6. Field Note 6:

The learner puts down the pen and stretches his organs then looks at the clock. Therefore, the teacher also immediately understands that the learning time is over and the teacher immediately ends the learning. The overall symbol that applies in the classroom is a rule that applies not only to learners also applies to teachers.

The communication process of the speaker and the speech partner is expected to run well and smoothly; they must work together. Working together well in the speaking process is one of them, namely behaving politely to the other party. The goal is to avoid communication congestion. Leech, said that the achievement as the purpose in conversation maintains social balance and the friendliness of the relationship in a conversation (Rusminto, 2009). The movements used by the teacher when teaching increase student attention to learning. Lecturers who make eye contact during learning allow them to give more comprehensive courses. Faces of smiling lecturers increase students' interest in learning. Lecturers who are enthusiastic in class stimulate students' interest in learning, and lecturers observe students while giving lectures to give more effective lectures (Gulec \& Temel, 2015).

\section{Courage in Language in Pragmatic Studies}

The view of politeness in pragmatic studies is described by several experts. Among these are Leech, Robin Lakoff, Bowl, and Levinson. The principle of politeness has several maxims, namely the maxim of wisdom (tact maxim), the generosity maxim (generosity maxim), the maxim of acceptance (approbation maxim), the modesty maxim (modesty maxim), the maxim of compatibility (agreement maxim), and the sympathy maxim (sympathy maxim). The principle of politeness is related to two conversation participants, namely oneself (self) and others (other). The self is a speaker, and the other person is the opposite of the speech (Wijana \& Rohmadi, 2010). Leech (Rusminto, 2009) divides the principle of politeness into the following six maxims.

a. Maxims Wisdom

Wise wisdom contains principles, namely: 1) Make the loss of others as small as possible; and 2) Make the other party as much profit as possible.

Data 1. Field Note 1:

Teacher: Today, you explain the group material for the presentation and the drawing will also be decided today, but you will advance to the group presentation three weeks from now. This week I present the material, next week I am still, and the third week you will start performing for presentations.

Learner: Oh, so not next week, sir, and papers will be collected when presenting?

Teacher: Yes, correct.

Based on the speech above the instructor states the form of politeness by obeying the wisdom maxims. Speakers provide benefits to their speech partners. Context of the speaker's sentence by giving the group work time in a long time. Students or speech partners will be happy if they are given more time to complete their assignments because they do not feel pressured.

\section{b. Maxims Generosity}

This maxim contains the following principles, namely 1) Make the smallest possible profits; and 2) Increase self-sacrifice.

Data 2. Field Note 2: 
Teacher: Let me erase the blackboard, please do your work.

Learner: yes, Sir!

The teacher volunteered to erase the blackboard when the situation of the learner was doing the assignment given by the teacher, and it was seen that one of the learners sitting on the front bench would move to the board and erase the blackboard. The sound of the maxim of generosity is how the speaker benefits the speech partner and adds sacrifice to himself by being willing to erase his writing to continue the subject matter.

c. Maxims Praise

This maxim has the following principles, namely 1) Slam other people as little as possible, and 2) Praise others as much as possible.

Data 3. Field Note 3:

Teacher: Who knows the definition of Language?

Learner: I sir (Raise hands and answer). Language is an expression of thoughts and feelings that uses speech as its primary means of expression.

Teacher: Good, applause, please.

The teacher asks questions to the learner, and there is a learner who tries to answer the teacher's questions. In this context, the teacher gives praise to the learner by stating the word "good, give applause, please ...". The phrase is included in the form of speech that adheres to the maxim of praise because the instructor does not at all criticize the learner instead gives praise.

\section{d. Maxims Modesty}

In the maxim of simplicity or maxim of humility contains the principle, namely 1) Praise yourself a little maybe; and 2) Imitate yourself as much as possible. Researchers found no data on humility maxims. The maxim of humility reads praise yourself as little as possible and criticize yourself as much as possible. Speakers must not boast of themselves. Even if you get a compliment, someone should not boast about feeling great and expressing greatness over achievement let alone mention something related to one's wealth or strength without asking to tell.

\section{e. Maxims Deal}

The maxim of the agreement is often referred to as the maxim of compatibility or agreement, this maxim contains the principle, namely 1) Reduce disagreement between yourself and others; and 2) Increase compatibility between yourself and others.

\section{Data 4. Field Note 4:}

Learner: Sir, we start college at five and then finish the first course at half-past 7. Can you enter at half-past seven?

(The context of the student's speech asks that the lecture be advanced as time goes on. It should come in at 19:00 WIB so that it is not too late in the evening after the lecture; the learner submits the request)

Teacher: If classmates agree. I'm okay.

The teacher tries to agree on the wishes and offers of the learner when the lecture time starts indeed at night and time effectiveness. Learners want time to enter the change of subject to be advanced, and the instructor agrees so that starting next week they start the lecture not on the schedule but early so that it will end early and the learner does not go home late at night. Teachers can remain firm on the actual schedule and take advantage of the time off to rest but because the teacher adheres to the maxim of agreement in courtesy so that the agreement occurs.

f. Maxims Sympathy

This maxim contains principles, namely 1) Reduce the sense of antipathy between yourself and others as small as possible; and 2) Enlarge sympathy between yourself and others.

Data 5. Field Note 5:

Teacher: Friends have shown that at 9 pm our lecture time has ended. Please pack up to go home and be safe on your way.

Speech acts that express sympathy such as congratulations, condolences, and other sayings that show respect for others. Also, politeness generally relates to one and another. The instructor, in this case, shows his sympathy by stating the word "be careful on the road" the form of the speech enters into the meaning of politeness with the maxim of sympathy. 


\section{CONCLUSION}

Learning includes embedded values and imprinted into a role model for learners. Teachers must have the attractiveness and character values displayed so that the object content and learning observation models become interesting. Learners watch a teacher's appearance in front of the class and try to record and then duplicate what they like. The more characteristics and uniqueness that is shown, the more the learner's attention to the figure who appears before him when learning takes place. Kinesics ability is an investment that is inherent in the application of the politeness of a teacher's Language. Showing an expression of sympathy, agreeing on a negotiation, showing a wise attitude, being generous, and always trying to praise the learner is an embodiment of how to maintain harmony between teachers and learners. The attitude that is no less important and inherent in the instructor's self is the kinesic attraction that causes the learner's pleasure and comfort when learning takes place.

\section{LIMITATION AND STUDY FORWARD}

The previous study with related research showed that most of the communication built between teachers and student were mostly done verbally by oral information share. Teachers mostly focused on what was said by their students to identify for any actions of them. In this study, it is added another aspect as available in the non- verbal Language to find more exact intention from their students by putting less attention to the verbal aspect shown. For future research, it is suggested to have a study in language learning by combining verbal and non-verbal aspects for a certain context of communication.

\section{CO-AUTHOR CONTRIBUTION}

Sincere gratitude is dedicated to the accomplishment of this paper to the first author in conducting initial research, setting up the framework of the manuscript and overall review within the content, the second author in collecting and analyzing the data, the third author in doing data interpretation and presentation and the fourth author in literature review along with the theoretical and conceptual background.

\section{REFERENCES}

1. Birdwhistell, R. L. (1955). Background to kinesics. Institute of General Semantic, 13(1), 10-18.

2. Buck, S., \& Tiene, D. (1989). The Impact of Physical Attractiveness, Gender, and Teaching Philosophy on Teacher Evaluations. Journal of Educational Research, 82(3), 172-177. https://doi.org/10.1080/00220671.1989.10885887

3. Caffi, C., \& Janney, R. W. (1994). Toward a pragmatics of emotive communication. Journal of Pragmatics, 22(3-4), 325-373. https://doi.org/10.1016/0378-2166(94)90115-5

4. Chaer, A., \& Agustina, L. (2004). Sosiolinguistik. Jakarta: Rineka Cipta.

5. Chiu, R. K., \& Babcock, R. D. (2002). The relative importance of facial attractiveness and gender in Hong Kong selection decisions. International Journal of Human Resource Management, 13(1), 141-155. https://doi.org/10.1080/09585190110092857

6. Dil, N. (1978). Kinesics od Affective Instability. Language Science, 1(2), 349-377. https://doi.org/10.1007/978-1-349-95810-8_1225

7. English, S. L. (1986). Kinesics in Academic Lectures. The ESP Journal, 4, 161-170. https://doi.org/10.1016/0272-2380(85)90018-6

8. Gabbott, M., \& Hogg, G. (2000). An empirical investigation of the impact of non-verbal communication on service evaluation. European Journal of Marketing, 34(3/4), 384-398. https://doi.org/10.1108/03090560010311911

9. Gkorezis, P., Bellou, V., \& Skemperis, N. (2015). Nonverbal communication and relational identification with the supervisor: Evidence from two countries. Management Decision, 53(5), 1005-1022. https://doi.org/10.1108/MD-11-2014-0630

10. Gulec, S., \& Temel, H. (2015). Body Language Using Skills of Teacher Candidates from Departments of Mathematics Education and Social Studies Education. Procedia - Social and Behavioral Sciences, 186, 161-168. https://doi.org/10.1016/j.sbspro.2015.04.149

11. Hans, A., \& Hans, E. (2015). Kinesics, Haptics, and Proxemics: Aspects of Non -Verbal Communication. IOSR Journal Of Humanities And Social Science Ver. IV, 20(2), 47-52.

12. Jolly, S. (2000). Understanding body language: Birdwhistell's theory of kinesics. Corporate Communications: An International Journal, 5(3), 133-139. https://doi.org/10.1108/13563280010377518

13. Jung, H. S., \& Yoon, H. H. (2011). The effects of nonverbal communication of employees in the family restaurant upon customers' emotional responses and customer satisfaction. International Journal of Hospitality Management, 30(3), 542-550. https://doi.org/10.1016/j.ijhm.2010.09.005

14. Kaiser, F. G., Glatte, K., \& Lauckner, M. (2019). How to make nonhumanoid mobile robots more likable: 
Employing kinesic courtesy cues to promote appreciation. Applied Ergonomics, 78(April 2017), 70-75. https://doi.org/10.1016/j.apergo.2019.02.004

15. Kliem, R. (2007). The Key to Effective Leadership. In Effective Communications for Project Management. https://doi.org/10.1201/9781420062489.ch11

16. Mey, J. L. (2009). Concise Encyclopedia of Pragmatics. In J. L. Mey (Ed.), Pragmatics. Oxford, UK: Elsevier's Rights Department.

17. Rahardi, K. (2005). Pragmatik: Kesantunan Imperatif Bahasa Indonesia. Jakarta: Erlangga.

18. Ratna, K. N. (2009). Stilistika, Kajian Puitika Bahasa, dan Budaya. Yogyakarta: Pustaka Pelajar.

19. Rusminto, N. E. (2009). Analisis Wacana Bahasa Indonesia. Bandar Lampung: Universitas Lampung.

20. Sugiyono. (2013). Metode Penelitian Kuantitatif dan $R \& D$. Bandung: Alfabeta.

21. Tarigan, H. G. (1993). Berbicara Sebagai suatu Keterampilan Berbahasa. Bandung: Angkasa.

22. Wijana, I. D., \& Rohmadi, M. (2010). Analisis Wacana Pragmatik. Kajian Teoridan Analisis. Surakarta: Yuma Pustaka. 